\title{
NASKAH AKADEMIK RANCANGAN PERATURAN DAERAH TENTANG BADAN USAHA MILIK DESA
}

M Chairul Basrun Umanailo ${ }^{1}$, Annisa Retrofilia Umanailo ${ }^{1}$, and Askar Daffa Sophia Umanailo $^{1}$

${ }^{1}$ Affiliation not available

December 21, 2020

\section{Hosted file}

NASKAH AKADEMIK BADAN USAHA MILIK DESA.pdf available at https://authorea.com/users/310886/ articles/498948-naskah-akademik-rancangan-peraturan-daerah-tentang-badan-usaha-milikdesa 